\title{
Constitutional guarantees of citizens' rights as a condition for sustainable environmental development
}

\author{
Maria Mukhlynina* \\ Institute of State and Law of the Russian Academy of Sciences, 10, Znamenka str., 119019 Moscow, \\ Russia
}

\begin{abstract}
Based on the analysis of the norms of the Constitution of Russia, the legal positions of the constitutional Court of the Russian Federation, strategic documents and other normative legal acts, the author examines the constitutional guarantees of citizens ' rights, determines the significance of the concept of sustainable development for ensuring environmental safety, as well as environmental development of Russia. The article analyzes individual UN sustainable development goals and national legislation designed to ensure the implementation of sustainable development policies and environmental protection. The interpenetration, interaction, and convergence of social relations leads to an increase in both legal mediation and integration processes. The author concludes that the legislation is becoming more and more environmentally friendly, these norms penetrate not only into acts regulating the economic development of the country, acts designed to prevent an environmental crisis, but also provide constitutional guarantees of human and civil rights to a favorable environment.
\end{abstract}

\section{Introduction}

Chapter 1 of the Russian basic law [1] contains norms that can be described as constitutional principles of environmental development, without forgetting, of course, about social, political and economic development, which is quite acceptable to consider as strategic goals of Russia's development.

Researchers Vagina O. V., Gaevskaya, E. Y. and Sawin, L. J., by a legal analysis of regulatory documents came to the conclusion that "modern environmental policy is the Foundation of the concept of sustainable development, the implementation of the right of everyone on favorable environment, strengthening the rule of law in the field of environmental protection and ecological safety" [2]. If we go back to the very beginning of the process of implementing sustainable development policies, the starting point is 1992, which was marked by the Rio conference, where more than 178 countries adopted Agenda 21. The agenda was a comprehensive plan of concrete actions of the global partnership for

\footnotetext{
* Corresponding author: muhlyninamm975@mail.ru
} 
sustainable development, realization of the constitutional rights of citizens, improvement of people's lives and protection of the environment. In September 2000, the Millennium Summit in new York adopted another important international document on sustainable development, the UN Millennium Declaration, and developed eight Millennium development goals aimed at reducing extreme poverty in the world by 2015 [3]. The Russian Federation supported this agenda, including with the aim of implementing constitutional guarantees of citizens ' rights in the field of ecology. Currently, the following main directions of state policy in the field of environmental development have been defined: improving the quality of life of citizens, maintaining the integrity of natural systems and life support functions for the sustainable development of the state and society, ensuring environmental safety, and improving public health.

The study of legal and organizational problems of ensuring the implementation of constitutional guarantees of citizens ' rights as a condition for achieving sustainable environmental development is reflected in the Works of vagina O. V., Gaevskaya E. Yu., Savina L. Ya. [2], Mukhlynina M. M. [7], Barkov A.V., Grishina Ya. S. [8], Kharkiv V. N. [6] and others.

\section{Methods}

The methodological basis of the research is the following General scientific methods: analysis and synthesis in the analysis of existing theoretical and methodological approaches and provisions, scientific developments of legal aspects of environmental protection; structural and logical analysis in the systematization of factors affecting environmental safety; factor analysis in determining the impact of indicators on the level of implementation of constitutional guarantees of citizens ' rights.

The information base of the research is legislation and regulations, statistical materials of state authorities $[1,3,4,5]$, scientific publications of Russian scientists on the problems of improving environmental protection and the implementation of constitutional guarantees of environmental rights of citizens in the aspect of the concept of sustainable development $[2,6,7,8]$.

In the course of the study, it is planned to analyze the legal features of environmental rights of citizens in modern conditions. In addition, the task is to justify approaches to assessing environmental parameters, identify and formulate possible directions for ensuring environmental safety, and the reality of ensuring constitutional guarantees of environmental rights of citizens.

\section{Results and discussion}

In order to ensure the implementation of the constitutional provision of paragraph 1 of article 17 Of the basic law of our country, it recognizes and guarantees to the population not only the basic rights and freedoms of man and citizen, but also a "block" of environmental rights and guarantees based on generally recognized principles and norms of international law. If we talk about the national level of environmental legislation, we can not fail to mention Federal law No. 7-FZ of January 10, 2002 "On environmental protection" [4], which contains norms, including those devoted to ensuring environmental safety and law and order, which directly affect the ability of the state to guarantee constitutional rights to citizens. Article 42 of the Constitution of Russia, in addition to proclaiming the "basic" right to a favorable environment, guarantees every citizen the opportunity to receive reliable information about its condition and to compensation for damage caused to their health or property by an environmental offense. The variety of consequences resulting from environmental offenses, the complex structure of environmental damage, as well as specific 
objects of environmental legal relations determine the need to apply environmental and legal, as well as civil norms to the regulation of public relations.

The constitutional and environmental rights of citizens are protected by another important body of justice in our country - the constitutional Court of the Russian Federation, which in its legal positions considers complex ambiguous norms of laws and other acts and law enforcement in accordance with their Constitution. In our case, The resolution of the constitutional Court of the Russian Federation of 07.06.2000 No. 10PM"On the case of checking the constitutionality of certain provisions of the Constitution of the Republic of Altai and the Federal law "On General principles of organization of legislative (representative) and Executive bodies of state power of the subjects of the Russian Federation" is interesting [5]. Having considered the case on the merits, the constitutional Court of the Russian Federation defined natural resources as a national property, which, according to V. N. Kharkiv, "allows, in the context of the preamble to the Constitution of Russia, to expand the subject structure of environmental relations by including the environmental interests of future generations of citizens of the Russian Federation in the sphere of protection by the current environmental legislation" [6]. Modern legal regulation and development of environmental protection and nature management practices in the context of the status of natural resources under consideration contributes to the state's long-term preservation of the country's natural resource potential and ensuring the implementation of constitutional guarantees of citizens ' rights. However, according to researcher Mukhlynina M., the issues of comprehensive analysis of the state environmental policy of the Russian Federation remain insufficiently developed [7].

\section{Conclusion}

Summing up, it can be noted that legislative support for the policy of sustainable socioeconomic development in Russia is an indispensable guarantee of the implementation of the environmental rights of the population to protect the environment. One of the possible ways to ensure sustainable socio-economic development is recognized as actively developing environmental entrepreneurship in the world at the present time. However, in Russia, according To Barkov A.V. and Grishina Ya. S. [8], "despite the adoption in 2000, at the inter - parliamentary Assembly of the CIS member States of the Model law on the basics of environmental entrepreneurship, this type of entrepreneurship has not yet been legalized", which does not contribute to its development, but does not stop its development. Returning to the issue of legal support for ways to solve problems in the framework of achieving the sdgs, the Russian Federation actively cooperates with foreign countries in this regard. As a suggestion to overcome legal and organizational problems in the implementation of constitutional guarantees of citizens ' rights, it is important to note that it would be advisable to introduce green standards at all levels of government and administration.

\section{References}

1. The Constitution of the Russian Federation (adopted by popular vote on 12.12.1993) (with amendments). Assembly of legislation of the Russian Federation, 04.08.2014, No. 31, article 4398.

2. O. V. Vagina, E.Yu. Gaevskaya, L.Ya. Savina, Business, Management and Law, 2, 27 (2018)

3. United Nations Millennium Declaration, https://www.un.org/ 
4. Federal law No. 7-FZ of 10.01.2002 (as amended on 27.12.2019) "On environmental protection". Collection of legislation of the Russian Federation, 14.01.2002, No. 2, article 133.

5. Resolution of the constitutional Court of the Russian Federation of June 7, 2000 No. $10-\mathrm{P}$ "On the case of checking the constitutionality of certain provisions of the Constitution of the Altai Republic and the Federal law "On General principles of organization of legislative (representative) and Executive bodies of state power of the subjects of the Russian Federation". Collection of legislation of the Russian Federation. 2000. No. 25. St. 2728.

6. V.N. Kharkiv, Environmental law, 4, 3 (2019)

7. M. Mukhlynina, E3S Web of Conferences. Actual Problems of Ecology and Environmental Management: Cooperation for Sustainable Development and Environmental Safety, APEEM 2020, 05008, (2020)

8. A.V. Barkov, Ya.S. Grishina, Civil law, 4, 8 (2018) 